Sharif University of Technology
Scientia Iranica
SCIENTIA
I RAN I CA

Research Note

\title{
Resilient cities, a key solution to safeguard the environment
}

\author{
Y. Aghajani ${ }^{\mathrm{a}}$, M. Abbaspour ${ }^{\mathrm{b}}$, A. Mohammadic ${ }^{\mathrm{C}}$ S. Reza Soltani ${ }^{\mathrm{d}}$, \\ D. Aghajani ${ }^{\mathrm{e}}$ and A. Ahmadi ${ }^{\mathrm{f}, *}$
}

a. Anesthesiology, Critical Care and Pain Department of Dr. Ali Shariati, Tehran University of Medical Sciences, Tehran, Iran.

b. School of Mechanical Engineering, Sharif University of Technology, Tehran, Iran.

c. Department of Environmental Management, Graduate School of the Environment and Energy, Science and Research Branch, Islamic Azad University, Tehran, Iran.

d. Department of Land-Use Planning and Environmental Assessment, Graduate School of the Environment and Energy, Science and Research Branch, Islamic Azad University, Tehran, Iran.

e. Department of Environmental Engineering, Graduate School of the Environment and Energy, Science and Research Branch, Islamic Azad University, Tehran, Iran.

f. Department of HSE Management, Graduate School of the Environment and Energy, Science and Research Branch, Islamic Azad University, Tehran, Iran.

Received 13 May 2015; received in revised form 28 August 2015; accepted 16 November 2015

\section{KEYWORDS}

Megacities;

Resilient city;

Sustainable city;

Safe environment;

Criteria.

\begin{abstract}
In the 21st century, the world population is growing at a spiraling pace. Much of this growth is occurring in developing countries, where access to food, sanitary water, education, and health is severely limited. The ever-increasing urbanization highlighted the need for sustainable development based on human-environment interaction. The excessive and unplanned expansion of cities has resulted in numerous environmental predicaments due to clearly emphasized economic issues at the expense of social and environmental concerns. The most significant features of megacities are indicated in this paper and the environmental, social, physical, and economic criteria are addressed in order to attain sustainability and resilience. To examine the practical use of these criteria, extensive studies and field activities were carried out at District 14 of Tehran Municipality. The results of this study highlight the desire of authorities to move toward sustainable development as their activities indicated environmental improvements during the 2009-2014 period. At the end, several recommendations are made based on the obtained results to speed up the move toward sustainability and resiliency.
\end{abstract}

(C) 2016 Sharif University of Technology. All rights reserved.

\section{Introduction}

Currently, more than half of the human population resides in cities and by 2030, about $60 \%$ of the

\footnotetext{
*. Corresponding author.
}

E-mail addresses: y-aghajani@razi.tums.ac.ir ( $Y$.

Aghajani); abbpor@sharif.edu (M. Abbaspour);

ali.mohamadi1964@gmail.com (A. Mohammadi);

s.rezasoltani@gmail.com (S. Reza Soltani);

dor_aghajani@yahoo.com (D.Aghajani)

ahmadyaida@yahoo.com (A. Ahmadi) world's inhabitants would live in cities with more than five million residents. Meanwhile, $95 \%$ of the future urbanization would take place in developing countries. Cities across the globe occupy only $2 \%$ of the main land; however, they consume $60 \%$ to $80 \%$ of the energy and cause $2 \%$ of the total carbon emissions. They deplete freshwater resources, endanger ecosystems, and strain public health. On the other hand, cities could play an essential role in the global green economy through improvements in transportation, building construction, energy conservation, water 
sanitation, sewage treatment, and addressing socioeconomic issues [1].

A very large city, typically one with a population of over ten million people, is defined as a megacity [2]. Megacities all over the world have destructive environmental effects that require governmental interventions to manage them. This calls for the redefinition of the urban management principles by the governments and metropolitan authorities. Otherwise, urban areas in developed and developing countries would be susceptible to adverse impacts of climate change, depletion of resources, lack of food security, and economic instability in the near future. These factors would significantly alter the status of urban and suburban areas in the coming decades. Thus, the term "resilient city" is being used to address the above-mentioned challenges in order to attain sustainability. A resilient city is one that has developed capacities to help absorb future shocks and stresses to its social, economic, and technical systems and infrastructures so as to still be able to maintain essentially the same functions, structures, systems, and identity [3]. Sustainability in a city can be defined as a safe environment, productive economy, and active community.

Since more than half of the global population resides in urban areas, there is no doubt that the issue of urban management is a priority for any given government in the world [4].

Urbanization as the transition phase from rural to urban population will grow rapidly in the coming years, and will continue especially in the developing countries [5]. Presently, more than half the population of Asian and African countries are living in rural areas. However, the trend is rapidly changing towards urbanization.

From 29 megacities of the world in 2014, TokyoYokohama in Japan tops the list with $37,555,000$ population, while London with $10,149,000$ residents is at the bottom and Tehran, the capital of Iran, with a population of 13,429,000 people is ranked 22nd [6].

The rapid urbanization and increase in the number of megacities have resulted in serious environmental and socio-economic predicaments and have created various challenges in urban strategic planning and policy making [6]. Some of these challenges are cities increasingly having to face rising population, worldwide and regional investments to generate employment, revenue and funds for development, high costs of living, economic disparity, increase in crime rate and dealing with the rising levels of pollution. There are also cities that cannot compete because of low productivity, economic instability, poverty, inequality, and social conflicts [7].

The international concerns about the issue of urban overpopulation are due to its impacts at the global scale, such as excessive exploitation of resources, air pollution, lack of food security, poverty, social discrimination, and vulnerability. These are serious challenges confronting urban policy makers and strategists. Studies conducted by various national and international networks highlight the urgent need for the development of well-defined strategies for expansion of cities, urban land use, and socio-economic management [8].

This paper discusses various elements of megacities and examines steps taken at District 14 of Tehran Municipality toward sustainability and resiliency in Iran.

\section{Features and challenges of megacities}

There are numerous large and wide cities all around the world. At the present time, urban population has been estimated to be around 3.5 billion of inhabitants and will probably be more than 5 billion by 2030 . The term "megacities" was defined for metropolitan agglomerations which hold more than 10 million of inhabitants [9].

As shown in Table 1, the following features are the major characteristics of megacities to be addressed for identification of their potential threats and opportunities at national, regional, and international levels [6].

The increase in number of megacities is considered as the driving force of the global economy that effectively influences the flow of goods, people, culture, and knowledge. Megacities are potentially unique concentration areas of skills and technical resources to improve the quality of life for large numbers of people.

According to the United Nations reports, megacities are struggling to reach a balance between the quality of life, economic competition, and preservation of the environment.

Megacities are the 21st century phenomena whose sheer size, complexity, and essential role as the global economic gateways have created many obstacles to sustainable urban development [1]. It is important to point out that only the environmental challenges are addressed in this article.

Regardless of the megacities' positive aspects, they have a long list of environmental problems. Builtup of water and air pollution, lack of proper waste management, and soil erosion are familiar issues for such cities worldwide. Thus, the main barriers to the sustainable expansion of megacities include [1]:

- Lack of public awareness;

- Lack of proper social behavior;

- Inadequate/insufficient technical knowledge;

- Lack of adequate infrastructures;

- Lack of compatibility between the college curriculum and the actual socio-economic needs; 
Table 1. Major characteristics of megacities.

\begin{tabular}{|c|c|}
\hline Megacities features & Factors \\
\hline Population density & Concentration of the human population in reference to space. \\
\hline Dynamism of growth & $\begin{array}{l}\text { Society: Population growth rate; } \\
\text { Economy: Real growth rate of the Gross Domestic Product (GDP); } \\
\text { Land: Suburbanization rate, land sealing rate. }\end{array}$ \\
\hline $\begin{array}{l}\text { Settlement, infrastructures, } \\
\text { and land ownership }\end{array}$ & $\begin{array}{l}\text { Number and the size of unofficial urban settlements; land-use alteration; quality } \\
\text { and the quantity of the urban infrastructures. }\end{array}$ \\
\hline Socio-economic inequalities & Poverty rate; unemployment rate; and mortality rate. \\
\hline Hazards and vulnerability & Mortality risk; economic risk; level of vulnerability determined for each risk. \\
\hline Urban governance & $\begin{array}{l}\text { Participation, rule of law, transparency, responsiveness, consensus; } \\
\text { orientation, equity, effectiveness, efficiency, and accountability Indicators; } \\
\text { i.e. corruption index. }\end{array}$ \\
\hline
\end{tabular}

- Lack of guidelines for effective public participation.

\section{Sustainable and resilient city}

Sustainable development is a broad term emphasizing the proper long-term use of resources. Sustainability refers to the procedure that could be repeated over and over without affecting other aspects of environment, while being cost-effective. Therefore, "sustainability" simply means to satisfy the needs of the present generation without endangering the well-being of the future generations [7].

A resilient city is built through engagement of its government, citizens, and other stakeholders in the process of disaster risk reduction, where specific actions are taken to identify, manage, and lessen the impacts of natural and human-induced hazards [10]. A city should have certain characteristics to be resilient against potential risks and natural disasters without incurring irreparable damages [11]. Such resilient city, by its capacity can withstand or absorb the impact of a hazard through resistance or adaptation, which enable it to maintain certain basic functions and structures to bounce back or recover from a crisis. Table 2 presents four categories of resilient and sustainable cities based on 12 criteria.

This paper reviews environmental features of a resilient and sustainable city, of which the elements are mentioned in Table 3. However, there are defined indices that determine the quality of each of these factors for sustainability and resiliency. For a case like air, presently several indices can be used such as AQI, AQHI, AQRI [12], or for the case of noise, there are several standards such as US Environmental Protection Agency (US.EPA) noise pollution standards; of course there are national and international regulations for different regions.

\subsection{Environmental category}

- Environment conservation. Protection of the urban environment plays a significant role in its sustainability. For example, the reduction of air pollution or greenhouse gases mitigates the climate change and its adverse consequences [13-18].

- Protection and expansion of green space. Green spaces not only reduce the greenhouse gases and improve climate, but also reduce runoffs and risk of flooding, because most cities with asphalt paved streets are vulnerable to flooding. Therefore, protection and expansion of green landscape have effective impact on prevention and mitigation of risks with ensuing financial damages [3,13,14,18].

- Optimized use of resources. It includes the reduction in consumption of resources and increase in use of clean or renewable resources and energy. Such steps can mitigate the damages during a crisis and help the sustainability and resiliency of the city $[3,15,18]$.

\section{Environmental activities toward sustainability and resiliency, District 14 of Tehran municipality}

District 14 with an area of $22.04 \mathrm{~km}^{2}$ located at the eastern part of Iran capital, Tehran, covers about $3.2 \%$ of this city. It is comparatively a small district with high population density. District 14 has 6 regions and 26 neighborhoods with 483,833 residents. Figure 1 shows the location of District 14 alongside other districts in Tehran [19]. 
Table 2. Considered environmental, social, physical, and economic criteria.

\begin{tabular}{ll}
\hline Categories & Criteria \\
\hline Environmental & $\begin{array}{l}\text { Conservation of the environment; } \\
\text { Optimized use of resources. }\end{array}$ \\
& Providing continuous education and training at schools and local communities to increase public \\
& awareness; \\
& Interaction with the social media; \\
& Communication with various communities and institutions. \\
& Establishment and improvement of infrastructures, monitoring the construction process; \\
& Risk assessment and determining the potential dangers and planning for their mitigation \\
& and implementing action plans; \\
& Defining and determining the organizational structure and the responsibilities for the \\
& management of crisis. \\
& Determining and allocating the required budget for the establishment and development of \\
& infrastructures and other effective steps to increase city resilience; \\
& Providing loans for the modernization of old buildings and reinforcement of weak structures \\
& or those located in high-risk areas; \\
& Ability to allocate the required budget in a crisis.
\end{tabular}

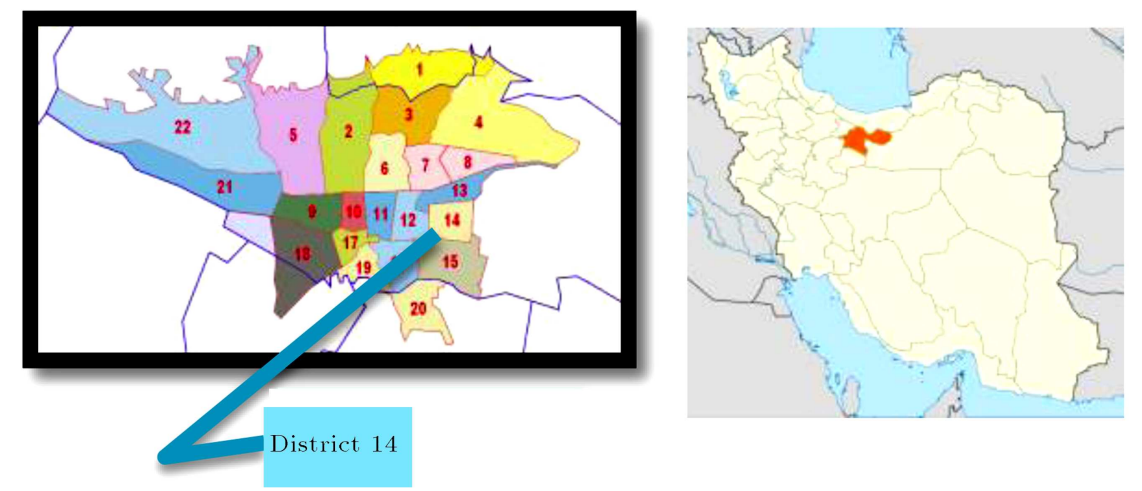

Figure 1. Location of District 14 in Tehran City's municipal divisions.

The following is a brief description of activities in District 14 during the 2009-2014 period.

\subsection{Environmental protection}

District 14 of Tehran Municipality has conducted measurements on air, ground water, and noise pollutions with subsequent implementation of ongoing mitigation measures since 2011. These actions have been in line with the conservation of the environment. The status of the district in terms of the above-mentioned issues is explained below:

- Air pollution in District 14. Air pollution is a serious problem in Tehran. Due to lack of proper and modernized model of urbanization, high concentration of population, and heavy traffic, District 14 is one of the most polluted areas of
Tehran. Thus, with the objective of air pollution reduction, District 14 developed a crisis map of air pollution in 2011. To this end, a lengthy study at 25 selected monitoring stations was conducted. Particulate matter of pollutants less than 2.5 micrometers $\left(\mathrm{PM}_{2.5}\right)$ was measured at the aforesaid stations. The results indicated that District 14 had $\mathrm{PM}_{2.5}$ concentrations above the permissible standards in accordance with the Iranian Department Of Environment (DOE) regulations during every monitored season [19]. Since the air pollution was above the permissible limits, actions have been taken to mitigate pollution and improve air quality of the district in recent years as a priority in its urban planning. Amongst these actions were the use of less polluting vehicles and enforcement of 
Table 3. Environmental elements of a resilient and sustainable city [22].

\begin{tabular}{|c|c|c|}
\hline Topic & $\begin{array}{l}\text { Factors determining } \\
\text { sustainability \& } \\
\text { resiliency of megacities }\end{array}$ & Issues influencing the factors \\
\hline \multirow{4}{*}{ Air } & Urban environmental quality & Air quality in urban areas \\
\hline & \multirow{3}{*}{$\begin{array}{l}\text { Environmental } \\
\text { management }\end{array}$} & Density of stationary control sites \\
\hline & & Number of supervised pollutants \\
\hline & & Number of polluted days \\
\hline \multirow{4}{*}{ Energy } & \multirow{3}{*}{ Energy usage } & Energy consumption per person \\
\hline & & $\begin{array}{c}\text { Energy consumption in each sector } \\
\text { (household, industrial, agricultural, } \\
\text { commercial, services, etc.) }\end{array}$ \\
\hline & & Amount of natural gas consumption per person \\
\hline & Urban action plan & Implementation of Environment and Energy plan \\
\hline \multirow{8}{*}{ Green Space } & \multirow{5}{*}{$\begin{array}{l}\text { Urban } \\
\text { environmental quality }\end{array}$} & Density of public green spaces \\
\hline & & Density of various green centers \\
\hline & & (urban parks, historical green areas, \\
\hline & & local parks, green belts, children \\
\hline & & playgrounds, gardens, etc.) \\
\hline & \multirow{3}{*}{$\begin{array}{l}\text { Environmental } \\
\text { management }\end{array}$} & Annual construction of new green spaces \\
\hline & & Annual statistics of green spaces \\
\hline & & Implementation of urban green plans \\
\hline \multirow{9}{*}{ Noise } & \multirow{7}{*}{$\begin{array}{l}\text { Environmental } \\
\text { management }\end{array}$} & Number of noise measurement stationary sites \\
\hline & & Installation of noise barriers \\
\hline & & Number of noise supervision camps \\
\hline & & $\begin{array}{l}\text { Number of public protests due to noise pollution } \\
\text { from industrial, traffic and repair sources }\end{array}$ \\
\hline & & Number of activities conducted by the municipality \\
\hline & & causing noise pollution (festivals, sports events, vehicles, etc.) \\
\hline & & Number of driving tickets for noise pollution \\
\hline & \multirow{2}{*}{ Urban action plan } & Implementation of noise zoning plan \\
\hline & & Implementation of noise reduction plans \\
\hline \multirow{19}{*}{ Transportation } & \multirow{3}{*}{ Infrastructural equipment } & Length of railroad infrastructures \\
\hline & & Density of railroads \\
\hline & & $\begin{array}{c}\text { Density of railroad lines per type (conventional } \\
\text { railroad, monorail, subway, etc.) }\end{array}$ \\
\hline & \multirow{7}{*}{ Density of vehicles } & Density of personal cars \\
\hline & & Density of transportation vehicles \\
\hline & & Density of taxis \\
\hline & & Number of urban vehicles per type (personal \\
\hline & & cars, buses, motorcycles, trucks, etc.) \\
\hline & & and fuel type (regular gasoline, unleaded \\
\hline & & gasoline, diesel, etc.) and their average age \\
\hline & \multirow{5}{*}{$\begin{array}{l}\text { Environmental } \\
\text { management }\end{array}$} & Number of sidewalks \\
\hline & & Length of bicycle paths \\
\hline & & Number of traffic limitation zones \\
\hline & & Number of free public parking \\
\hline & & Number of pay public parking \\
\hline & Passengers of & Number of passengers riding \\
\hline & transportation fleet & on buses, monorails, subway, etc. \\
\hline & \multirow{2}{*}{ Urban operational plan } & Implementation of urban traffic plan \\
\hline & & Innovative traffic control plans \\
\hline
\end{tabular}


Table 3. Environmental elements of a resilient and sustainable city [22] (continued).

\begin{tabular}{|c|c|c|}
\hline Topic & $\begin{array}{l}\text { Factors determining } \\
\text { sustainability and } \\
\text { resiliency of megacities }\end{array}$ & Issues influencing the factors \\
\hline \multirow{7}{*}{ Wastes } & $\begin{array}{l}\text { Production and } \\
\text { management of wastes }\end{array}$ & Collection of urban wastes \\
\hline & \multirow{6}{*}{$\begin{array}{l}\text { Environmental } \\
\text { management }\end{array}$} & $\begin{array}{l}\text { Separated collection of wastes based on their type (paper, } \\
\text { glass, plastic, aluminum, metal, wood, organic, etc.) }\end{array}$ \\
\hline & & Number of sanitary land fills \\
\hline & & Number of garbage bins \\
\hline & & Number of camps promoting \\
\hline & & separation of wastes from the origin \\
\hline & & The amount of fine for illegal disposal of wastes \\
\hline \multirow{5}{*}{ Water } & \multirow{3}{*}{ Water resources } & Water consumption per capita \\
\hline & & Household consumption per capita \\
\hline & & $\begin{array}{c}\text { Consumption per capita (household, industrial, } \\
\text { agricultural, commercial, etc.) }\end{array}$ \\
\hline & \multirow{2}{*}{$\begin{array}{l}\text { Environmental } \\
\text { management }\end{array}$} & Number of sewage treatment facilities \\
\hline & & Percentage of sewage network subscribers \\
\hline \multirow{3}{*}{$\begin{array}{c}\text { Demographic } \\
\text { land } \\
\text { information } \\
\end{array}$} & \multirow{3}{*}{ Public indicators } & Lands across the urban area \\
\hline & & Population density \\
\hline & & Number of housing units \\
\hline
\end{tabular}

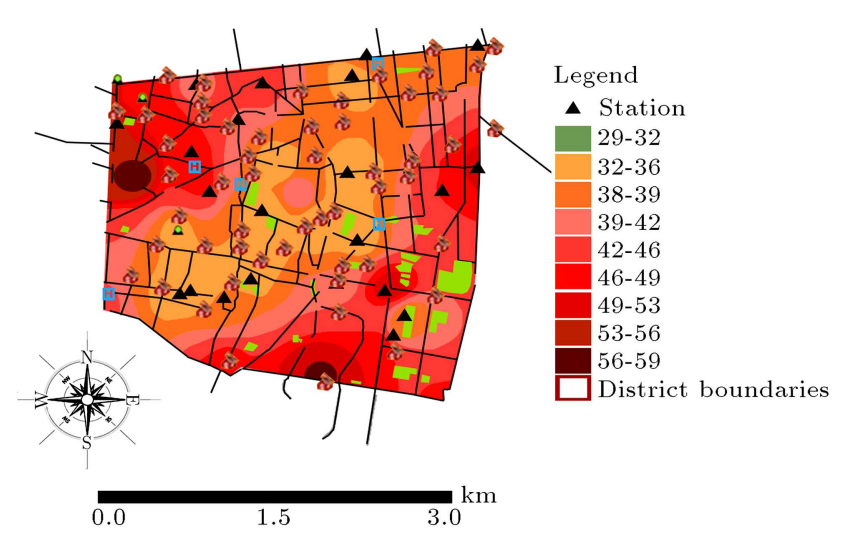

Figure 2. A sample of $\mathrm{PM}_{2.5}$ (micrometers) distribution at District 14 [19].

regular technical inspection, promoting bicycle rides to reduce fossil fuel consumption, and development of green spaces to reduce air pollution. Figure 2 illustrates the distribution of $\mathrm{PM}_{2.5}$ at District 14 .

- Noise pollution in District 14: The measurement of noise pollutants was conducted in 2011 and specific steps were envisioned to reduce noise pollution till 2014. Thus, 91 stations were selected and noise equivalent levels were measured three times on Saturdays to Wednesdays in the morning (7-9), noon (12-3), and afternoon (5-8). Based on the results of this research, noise equivalent levels in all stations were above the standards [20].
Due to high level of noise pollution, some recommended measures for control and mitigation were put on the district agenda. Figure 3 illustrates the recommended steps. Some of these actions include increase in highways green spaces through plantation of dense vegetation with a combination of broad-leaf and needle-leaf trees, construction of noise absorbing levees covered with vegetation, and use of acoustic walls based on technical specifications as shown with dark lines in Figure 3. Also, some of the streets were widened as indicated with red lines in Figure 3.

With respect to the potential impacts of high noise levels on certain residential areas, engineering measures are being implemented during the building construction, including the use of double layered windows, thick glasses, insulated external walls, ceilings and floors, and the use of noise-absorbing building materials. All of these measures are being implemented in this district to mitigate noise pollution.

- Ground water contamination in District 14: The assessment of ground water pollution and prevention of its contamination are essential. Sampling of 16 wells (their locations are shown in Figure 4) used for green space irrigation was conducted in order to identify the qualitative status of ground waters and the factors threatening their quality. The 




Figure 3. Recommended actions to mitigate noise pollution in District 14 [20].
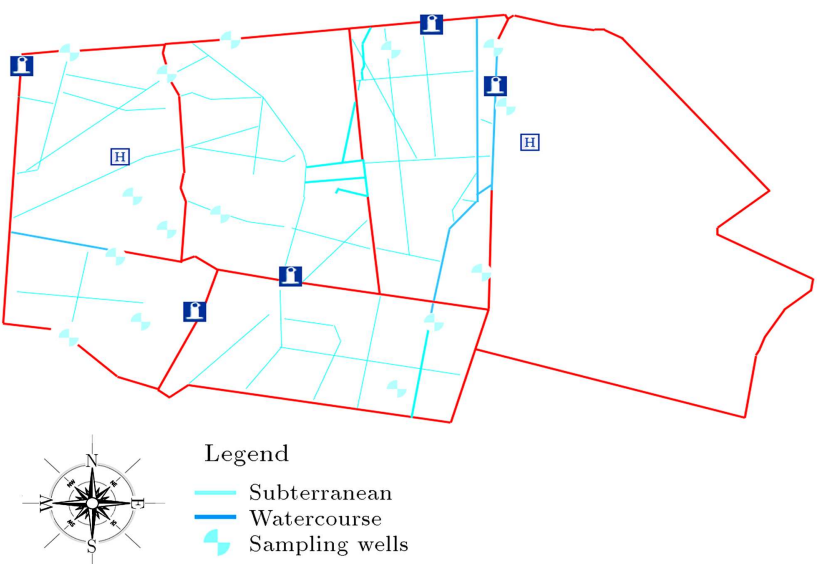

Figure 4. Location of sampling wells in District 14 [21].

measured factors were physical parameters (temperature, color, and odor), chemical parameters $(\mathrm{pH}$, EC, TSS, and TDS), anions $\left(\mathrm{NO}_{2}, \mathrm{NO}_{3}, \mathrm{Cl}, \mathrm{SO}_{4}\right.$, $\mathrm{CO}_{3}$, and $\mathrm{HCO}_{3}$ ), cations $(\mathrm{Mg}, \mathrm{K}$, and $\mathrm{Na}$ ), heavy metals ( $\mathrm{Pb}, \mathrm{Ag}$, and $\mathrm{Cd}$,), and MTBE. Comparison of the 17 measured parameters with the standard levels (the chemical parameters and the anion concentrations were compared with FAO standards, the heavy metal concentrations were compared with Australian Water Quality Guidelines) revealed that these wells were within the accepted standard limits, which are presented in Table 4, and suitable for agricultural purposes based on the Wilcox classification [21]. Reduction in use of pesticides and chemical fertilizers as well as practicing environmental protection measures throughout painting and washing of urban structures are on the agenda of the municipality. Measurements of ground water and comparison of them with international standards show that concentrations are within standard limits, as indicated in Table 4.

\subsection{Protection and expansion of green space}

The green space area at District 14 has increased from $2,430,000 \mathrm{~m}^{2}$ in 2009 to $2,857,600 \mathrm{~m}^{2}$ in 2014. Also, the nearby forest called Ghasr-e-Firouzeh has been expanded from 355 hectares to 369 hectares during the same period. Although the expansion plan is considerable, there are still potentials to extend and reclaim more lands. With the aid of proper planning, such as implementation of drip irrigation, use of recycled waste water, etc., the green space per capita in the district can reach more than 6.08 square meters in the future; the present value is around 5 square meters.

\subsection{Optimized use of resources}

Despite the steps taken for utilization of renewable energies, reduction of waste, and recycling, there are many shortcomings.

Lack of optimized use of rain water and local water resources, and inability to suitably exploit solar and wind energies are the main deficiencies in District 14 . However, there are certain measures outlined to attain the optimized use of resources and energy.

Table 4. Minimum, maximum, and average amounts of parameters of the ground water in the region [21].

\begin{tabular}{lccccccccc}
\hline \multirow{1}{*}{ Parameter } & \multicolumn{9}{c}{ Analysis } \\
\cline { 2 - 9 } & $\begin{array}{c}\text { Nitrate } \mathbf{N O}_{3}^{-} \\
(\mathbf{m g} / \mathbf{L})\end{array}$ & $\begin{array}{c}\mathbf{N O}_{2}^{-} \\
(\mathbf{m g} / \mathbf{L})\end{array}$ & $\begin{array}{c}\mathbf{S O}_{4}^{2-} \\
(\mathbf{m e q} / \mathbf{L})\end{array}$ & $\begin{array}{c}\mathbf{C O}_{3}^{2-} \\
(\mathbf{m e q} / \mathbf{L})\end{array}$ & $\begin{array}{c}\mathbf{H C O}_{3}^{-} \\
(\mathbf{m e q} / \mathbf{L})\end{array}$ & $\begin{array}{c}\mathbf{C l}^{-} \\
(\mathbf{m e q} / \mathbf{L})\end{array}$ & $\begin{array}{c}\mathbf{N a} \\
(\mathbf{m e q} / \mathbf{L})\end{array}$ & $\begin{array}{c}\mathbf{K} \\
(\mathbf{m e q} / \mathbf{L})\end{array}$ & $\begin{array}{c}\mathbf{M g} \\
(\mathbf{m e q} / \mathbf{L})\end{array}$ \\
\hline Average & 106.96 & 0.26 & 2.69 & 0 & 4.85 & 4.23 & 5.87 & 0.055 & 2.25 \\
Maximum & 297 & 3.1 & 5.95 & 0 & 6.96 & 9.94 & 12.21 & 0.117 & 2.95 \\
Minimum & 33 & 0.06 & 1.66 & 0 & 2.95 & 2.99 & 3.08 & 0.033 & 1.63 \\
Median & 102.15 & 0.06 & 2.35 & 0 & 4.91 & 3.97 & 4.95 & 0.049 & 2.21 \\
Acceptable max [23] & 10 & 5 & 20 & 1 & 10 & 30 & 40 & 0.051 & 5 \\
Acceptable min [24] & 0 & 0 & 0 & 0 & 0 & 0 & 0 & 0 & 0 \\
\hline
\end{tabular}


Table 5. Environmental criteria as the city resilience indices and actions taken by Tehran Municipality, District 14 .

\begin{tabular}{|c|c|c|}
\hline Classification & Criteria & Actions taken by Tehran Municipality, District 14 \\
\hline \multirow{7}{*}{ Environmental } & \multirow{2}{*}{$\begin{array}{l}\text { Environmental } \\
\text { conservation }\end{array}$} & $\begin{array}{l}\text { Attainment of ISO } 14001 \text { certificate in } 2009 \text { and its extension } \\
\text { for } 5 \text { consecutive years }\end{array}$ \\
\hline & & $\begin{array}{l}\text { Studying the pollution sources (air, ground water, and noise pollutions) } \\
\text { and existing pollutions in the region, eventually providing } \\
\text { an action plan to remove or control them }\end{array}$ \\
\hline & $\begin{array}{l}\text { Conservation } \\
\text { and expansion of } \\
\text { green landscape }\end{array}$ & $\begin{array}{c}\text { Expanding the green landscape from } 2430000 \mathrm{~m}^{2} \\
\text { in } 2009 \text { to } 2857600 \mathrm{~m}^{2} \text { in } 2014 \text {, expansion of Ghaser-e- Firouzeh } \\
\text { Forest from } 355 \text { hectares in } 2009 \\
\text { to } 369 \text { hectares in } 2014\end{array}$ \\
\hline & \multirow{4}{*}{$\begin{array}{l}\text { Optimal use } \\
\text { of resources }\end{array}$} & $\begin{array}{l}\text { Use of renewable energies, like solar, through } \\
\text { installation of } 7 \text { solar water }\end{array}$ \\
\hline & & heaters and 64 solar light stands in parks \\
\hline & & $\begin{array}{l}\text { Use of local water resources and wells } \\
\text { for the irrigation of green spaces }\end{array}$ \\
\hline & & $\begin{array}{l}\text { Increasing the separation and recycling of urban wastes from } \\
19.15 \% \text { to } 22.1 \% \text { with potential for future activities. }\end{array}$ \\
\hline
\end{tabular}

The pertinent environmental criteria and the actions taken by District 14 are listed in Table 5 .

According to the results of this study, the status of several environmental criteria, such as environmental conservation, expansion of green space, and optimal use of resources, has improved from 2009 to 2014.

\section{Conclusion for the attainment of resilient city and safe environment}

The expansion of cities has increased the population density, created various types of environmental pollutions, raised energy consumption, and produced greater amounts of waste. Therefore, there has been great environmental impact at local and global levels that require profound urban management and planning.

This paper evaluated the sustainability and resiliency of District 14 of Tehran Municipality from the environmental perspective. Outcomes of this research indicate that certain criteria have improved significantly during the 2009-2014 period.

This was achieved by senior management's commitment to environmental conservation, green space development, obtaining ISO 14001 as well as HSE management system certificates, and performing detailed studies on air, noise, and water pollution. Subsequently, effective measures have been taken to mitigate the adverse effects of environmental pollution and a monitoring plan has been implemented through an annual environmental auditing program.

The local authorities intend to move towards resiliency and sustainability not only to safeguard the environment, but also to tackle socio-economic issues and to initiate preventive measures combating natural disasters. However, the study results indicate that there is still a long way to go in other important issues such as optimized utilization of water and energy resources. Albeit, the overall resilience status of District 14 has increased during the past 5 years. It could be concluded that the ultimate benefits of resilient and sustainable cities outweigh the initial investment by the national and local governments. The long-term national goal is to establish a network of resilient cities.

Although economic activities result in better individual and collective well-being of citizens, they usually instigate individual, social, and environmental tensions. On the other hand, economic recessions in large populated areas instigate unemployment, weaken social cohesion, disturb social security, and neglect environmental issues.

Therefore, sustainability of cities requires all the environmental and socio-economic ingredients coupled with public awareness and strong commitment to conduct the envisioned tasks including:

- Development of new plans and/or revision of the present plans;

- Establishment of new priorities;

- Utilization of resources for sustainable causes;

- Cooperation with other legal entities in the regions to attain sustainability [11].

Other proper activities for future achievements can be listed as follows:

- Promotion of the use of alternative energy resources;

- Construction of energy-efficient buildings;

- Using higher energy-efficient vehicles;

- Taking actions to combat the emission of Greenhouse Gases ( $\mathrm{GHG}$ ), especially $\mathrm{CO}_{2}$; 
- Recycling water and waste;

- Utilizing vegetation coverage to filter pollution and absorb atmospheric carbon dioxide;

- Cooperation with governmental institutions and municipalities;

- Cooperation with higher education institutions and executive; organizations;

- Conducting urban repair and maintenance plans;

- Reducing air pollution caused by urban transportation vehicles;

- Promotion of green construction and sale;

- Taking actions to mitigate the emission of GHG gases;

- Decrease in the use of pesticides in urban areas;

- Promotion of environmental preservation;

- Encouraging use of public transportation;

- Improving and optimization of the transportation infrastructures;

- Improving and expansion of the infrastructures of the green city;

- Participation in the local, national, and international meetings and sharing the attained experiences with them and eventually joining the global network of sustainable cities;

- Using endemic knowledge alongside the scientific studies in order to find ways to combat the potential risks by recognizing the intrinsic value of local knowhow.

Since the nature of each megacity can be different in terms of geographical, social, economic, and other aspects, further studies are required in order to be able to clarify required specifications for the factors of resiliency.

\section{References}

1. Ulrich, E. and Zechbauer, U. "Megacity Challenges: A stakeholder perspective" (2007).

2. "Oxford Dictionary," [Online]. Available at: http://www.oxforddictionaries.com/definition/english/ megacity (2014).

3. Resilience Alliance "Urban resilience, a resilience alliance initiative for transitioning urban systems towards sustainable futures, resilience alliance", [Online]. Available at:

http://www.resalliance.org/files/1172764197. urbanresilienceresearchprospectusv7feb07.pd. ( 2007).

4. Urban Challenge, UN-HABITAT [Online]. Available at:

http://www.unhabitat.org/content.asp?typeid=19\& catid $=540 \&$ cid $=5027 \&$ activeid $=5025$ (2012).
5. UNFPA, The State of the World Population 2007 [Online]. Available at: http://www.unfpa.org/swp/2007/presskit/pdf/sowp 2007_eng.pdf.( 2007).

6. Kötter, T. and Friesecke, F. Developing urban Indicators for Managing Mega Cities [Online]. Available at: www.isbk.uni-bonn.de. [Accessed] (2013).

7. Chen, H., Jia, B. and Lau, S. "Sustainable urban form for Chinese compact cities: Challenges of a rapid urbanized economy", Habitat International, pp. 28-40 (2008).

8. Demographia World Urban Areas 10th Annual Edition, [Online]. Available at: http://demographia.com/db-worldua.pdf. (2014).

9. Ziv, J.-C. and Cox, W. "Megacities and affluence transport \& land use considerations", in World Conference on Transport Research, Berkeley (2007).

10. UNISDR, Making Cities Resilient Report 2012. My City is Getting Ready! A Global Snapshot of How Local Governments Reduce Disaster Risk, Second Edition (2012).

11. UN-HABITAT, Planning Sustainable Cities Global Report on Human Settlements, Malta: Gutenberg Press (2009).

12. Ahmadi, A., Abbaspour, M., Reza, A. and Abedi, Z., "Air Quality Risk Index (AQRI) and its application for a megacity" International Journal of Environment Science and Technology, 12, pp. 3773-3780, DOI 10.1007/s13762-015-0837-7 (2015).

13. Shaw, R., City Profile: Climate and Disaster Resilience, UNISDR, [Online]. Available at:

http://www.unisdr.org/we/inform/publications/8168. (2009).

14. United Nations International Strategy for Disaster Reduction (UNISDR), How to Make Cities More Resilient, a Handbook For Local Government Leaders. [Online]. Available at: http://www.unisdr.org/files/26462_ handbookfinalonlineversion.pdf.( 2012).

15. Silva, J. and Parker, E., Visions of a Resilient City. Arup and Engineers Without Borders UK, (2012) [Online]. Available at:

http://publications.arup.com/Publications/V/ Visions_of_a_resilient_city.aspx

16. Alcerreca, B., Balbontin, P., Hernández, N., Hernández, G., Mendoza, L., Parra, H., Soto, P., Tenorio, J. and Villaseñor, E. "Climate action planning for municipalities: An opportunity for resilience", In 4 rd Global Forum on Urban Resilience \& Adaptation, Bonn, Germany (2013).

17. Nurhadi, M., Amrullah, A. and Tränkler, J. "Integrated climate action planning a methodology to increase Indonesian cities' resilience", In 4rd Global Forum on Urban Resilience \& Adaptation, Bonn, Germany (2013). 
18. Silva, J. and Morera, B. "City resilience framework: city resilience index", Arup International Development and Rockefeller Foundation (2014), [Online]. Available at:

http://www.rockefellerfoundation.org/uploads/files / e4830599-c2a7-4049-a002-4031f82850e3.pdf.

19. Abbasspour, M., Mansouri, N. and Abooli, M. "Survey of seasonal changes in PM 2.5 and making crisis map of it (case study: District 14 of Tehran municipality)", In Second National Conference on Air and Sound Pollution Management, Tehran, Sharif University (2013).

20. Karimi, E., Nasiri, P., Abbaspour, M. and Monazam, M. "Surveys of sound pollution in region 14 of Tehran", Human \& Environment, 23, pp. 1-12 (2013).

21. Shirani, Z., Abbaspour, M., Javid, A. and Taghavi, L. "Ground water pollution assessment in urban area (case study: District 14 of Tehran municipality)", Human \& Environment, 24, pp. 1-16 (2013).

22. Donatiello, G., Environmental Sustainability Indicators in Urban Areas: An Italian Experience, National Statistical Institute of Italy (2001).

23. Ayers, R. and Westcot, D., Water Quality for Agriculture, FAO Irrigation and Drainage paper, (1985) [Online]. Available at: http://www.fao.org/docrep/003/t0234e/t0234e00htm.

24. ANZECC \& ARMCANZ, Australian Water Quality guidelines for Fresh and Marine Water [Online]. Available at:

http://www.environment.gov.au/water/publications/ quality/index.htm.( 2000).

\section{Biographies}

Yasaman Aghajani is board certified anesthesiologist, and critical care and pain specialist at Tehran University of Medical Sciences. She received her Doctor of Medicine from Tehran Islamic Azad University of Medical Sciences in 2009. She is member of Medical Council of Islamic Republic of Iran and Iranian Society of Environmentalists. Her research interests include health, safety, environment, disaster management, and emergency responses.

Madjid Abbaspour is a Full Professor and the Head of Marine Group in the School of Mechanical Engineering at Sharif University of Technology (SUT) in Iran. He also heads the Center for Environment and Energy Research and Studies (CEERS) and the Graduate School of Environment and Energy at Science and Research Branch of Islamic Azad University (IAU). Furthermore, he is serving as scientific adviser to the Head of High Expediency Council of Islamic Republic of Iran. His research interests are marine industries, ocean engineering, renewable energy, energy engineering, and environmental engineering.
Ali Mohammadi, PhD, has nearly 30 years of professional experience in managing engineering and environmental projects in the United States and Iran. His qualifications were strengthened by his seven years of collaboration with the GEF-UNDP Caspian Environment Program encompassing projects in the Russian Federation, Kazakhstan, Turkmenistan, Azerbaijan, and Iran. Currently, he is a full-time faculty member of the Graduate School of Environment and Energy at IAU, Iran.

Saba Reza Soltani is an Adjunct Professor in the Department of Environment and Energy, Science and Research Branch of the Islamic Azad University. Concurrently, she has been the manager of HSE and Environmental Studies Bureau in District 14 of Tehran Municipality since 2008. She received her $\mathrm{PhD}$ degree in Environmental Sciences at the Islamic Azad University in 2012. Her current research projects focus on environmental risk assessment, land-use planning, and land-suitability assessment. Her areas of expertise include urban landscaping, land development, and sustainable development. She has co-authored numerous journal publications and conference articles.

Dordaneh Aghajani is PhD student of Environmental Engineering at Science and Research Branch, Islamic Azad University. She received her bachelor's degree in the field of Information Technology Engineering and master's in Information Technology Management (Advanced Information System). She is currently working as an expert in the field of energy and environment in order to use her knowledge in the field of information technology to increase the renewable energy consumption, using the web-GIS system and other available information technology tools. She is a member of the Center for Environment and Energy Research \& Studies and is also giving consultation to some private companies in the field of environment and energy. She has participated in many projects, including a national project named Technology Need Assessment which has been prepared for UNFCC.

Aida Ahmadi is an expert in the field of HSE. She is a faculty member at Islamic Azad University, Science and Research Branch (SRBIAU), and has been working with the Center of Environmental and Energy Research \& Studies (CEERS) for the past 10 years. She is also an active member of Iranian Society of Environmentalists. She has participated in different projects related to her field of expertise. The topics of her research interests are in the related fields of environment, health, safety, risk management and HSE, renewable energy, green productivity, and environmental impact assessments and auditing. 